\title{
Introduction: Kant's philosophical method and contemporary perspectives in epistemology, metaphysics, philosophy of mind, philosophy of science and ethics
}

\section{Gabriele Gava ${ }^{1}$}

Published online: 7 January 2021

(c) The Author(s), under exclusive licence to Springer Nature B.V. part of Springer Nature 2021

If one considers the history of analytic philosophy, one can easily appreciate why Kant's views in epistemology, metaphysics and the philosophy of mind have generally been regarded with suspicion. Take Kant's doctrine of transcendental idealism, his account of space and time as forms of intuitions, or his views on causality. These are just a few examples of Kant's ideas that have enjoyed very little success among analytic philosophers. ${ }^{1}$ Beginning in the 1960 s, however, a renewed interest in Kant's works in theoretical philosophy emerged among analytically-minded philosophers. Thanks in large part to Peter Strawson's use of transcendental arguments as tools against scepticism (1959) and his interpretation of the first Critique (1966), it appeared that Kant's approach could be made to work if one focused not so much on his substantive views in epistemology, metaphysics or the philosophy of mind, but rather on the strategy of argument he used. Indeed, as a result of this renewed interest in Kant, transcendental arguments were put at the centre of a dynamic debate during the second half of the last century (for a reconstruction of the debate see Gava 2017a,b; Pereboom 2019; Stern 2019).

Within this debate, however, transcendental arguments were subject to serious criticism, which questioned their ability to refute radical scepticism (for famous criticisms, see Stroud 1968; Brueckner 1983, 1984). In answering these worries, some scholars have argued that transcendental arguments can be successful if they are re-conceived along more 'modest' lines. They suggested, for example, that transcendental arguments can establish not that the world must be a certain way, but

\footnotetext{
${ }^{1}$ One must tell a different story for Kant's ethics. A Kantian approach to ethics is not only eminently respectable in contemporary analytic philosophy, but also one of the main views that animate the debate. Another field of research where a Kantian approach has had some fortune - though not as much as in ethics - is the philosophy of science. A good example of a contemporary Kantian approach in this area that has attracted much attention is Michael Friedman's relativized a priori (2001).
}

Gabriele Gava

gabriele.gava@unito.it

1 University of Turin, Turin, Italy 
only that we must believe that the world is a certain way (see Stroud 1994). Alternatively, they meant that even if transcendental arguments are unable to refute a 'radical' sceptic, they could work for other kinds of scepticism, for example a 'justificatory' sceptic, who doubts that we can provide any kind of justification for our beliefs, including fallible justifications (Stern 2000). Notwithstanding these attempts to defend modest versions of transcendental arguments, in recent years the interest in transcendental arguments has waned. As a consequence, the prospect of applying Kant's philosophical method to current debates in metaphysics, epistemology and philosophy of mind has experienced a similar fate. ${ }^{2}$

The aim of this special issue is to show that analytic philosophers can still find inspiration in Kant's philosophical method (or methods) and apply his distinctive approach to different issues and problems. It pursues this aim in four different ways. First, it offers new transcendental arguments and applies these in new frameworks. Second, it sheds light on aspects of Kant's method that have been unjustly regarded with suspicion by analytic philosophers. Third, it highlights methodological aspects of Kant's approach in those parts of his philosophy that have already influenced discussions in analytic philosophy, such as his ethics. Finally, it shows how a distinctive Kantian approach can help us to make progress with specific problems that are debated nowadays. The papers belonging to this last group do not always focus directly on Kant's method. Nonetheless, they highlight how Kant's views in certain subfields of theoretical philosophy can provide new materials for inaugurating a fresh perspective in present discussions.

In the first paper, titled 'A Kantian Virtue Epistemology: Rational Capacities and Transcendental Arguments', Karl Schafer develops a transcendental argument that aims to show that the acceptance of certain basic forms of thought is a necessary condition for rationality. Schafer provides two examples of forms of thought whose role for rationality can be explained in such a way: explanatory inference (e.g. abduction or inference to the best explanation) and perceptual belief. What is original in Schafer's transcendental argument is that he makes use of an account of rationality that is not normally associated with Kant, but that Schafer beliefs is Kantian through and through. According to this account, rationality is not only understood as a faculty or capacity (a view that one can easily ascribe to Kant). Rather, since we can identify a telos of this capacity, which Schafer spells out as understanding, rationality can be also understood as a virtue.

The concept of a 'faculty' also plays a central role in the second paper, by Thomas Land, titled 'Epistemic Agency and the Self-Knowledge of Reason: on the Contemporary Relevance of Kant's Method of Faculty Analysis'. Land argues that Kant's method of faculty analysis has wrongly been ignored by contemporary philosophers. Central to this method is the idea that it is constitutive of certain capacities that the

\footnotetext{
2 There are, however, certain aspects of Kant's theoretical philosophy that have recently attracted some attention, even outside Kant scholarship, such as his account of modality (Leech 2012; Stang 2016) or his theory of assent or 'taking-to-be-true' (Fürwahrhalten) (see Chignell 2007a; Chignell 2007b). Additionally, one should mention that interest in Kant's contribution to the debate between conceptualists and non-conceptualists has arisen from McDowell's interpretation of Kant's philosophy of perception (see McDowell 1996).
} 
bearer of the capacity has an understanding (perhaps highly implicit and inarticulate) of the norms that govern its exercise. Faculty analysis seeks to give an account of the nature of such a capacity by making this understanding explicit. Land argues that the idea about capacities is shared by those contemporary philosophers who hold a so-called 'agentialist' view of belief (where this is the view that having a belief involves an exercise of epistemic agency). It follows that the philosophical commitments that give the method of faculty analysis application constitute a live option in contemporary debates. Accordingly, the method itself is a live option too.

The third paper, 'Methodological Reflections on Kant's Ethical Theory', written by Robert Audi, is the only one dedicated to Kant's practical philosophy. Audi provides a reconstruction of Kant's methodology based both on his methodological statements and his actual procedure in formulating and defending some of his views. He compares Kant's views with W. D. Ross's rationalist intuitionism. While Kant's approach to ethics, on the one hand, can be broadly described as developing a 'top-down' methodology and Ross, on the other, is a 'bottom-up' theorist, Audi ably shows important points of convergence between their views. In a last step, Audi illustrates how it would be possible to incorporate further elements of Ross's intuitionism in a Kantian approach to ethics and give rise to a form of 'Kantian intuitionism'.

In the fourth paper, 'Kant on the Epistemic Role of the Imagination', Tobias Rosefeldt investigates how Kant's account of the imagination can further the present debate on modal knowledge. In particular, he focuses on the possibility of appealing to the imagination for taking into account certain epistemologically significant modal distinctions. Rosefeldt highlights important similarities between Kant's use of the imagination to determine what is really, and not merely logically, possible and recent accounts of how imagining can provide evidence for metaphysical, in contrast to conceptual, possibility. Rosefeldt also points out what is distinctive about Kant's idealist approach and sketches the directions that an application of Kant's ideas on the imagination to the current debate on modal knowledge may take.

The fifth paper, by Jessica Leech, also considers Kant's philosophy of modality. In 'The Function of Modal Judgment and the Kantian Gap', Leech reconstructs Kant's answer to the question regarding the function of modal judgments in the Critique of Judgment. According to Leech, Kant argues that 'a capacity to make modal judgments using (categorial) modal concepts is required for our capacity for objective representation, in light of our split cognitive architecture'. Leech then explores how Kant's answer to this question may in fact improve upon contemporary accounts. It is a merit of Kant's approach that it shows how not only a distinction between the actual and the non-actual but also one between the actual and the possible is a condition for objective thought.

In the sixth paper, 'What Real Progress Has Metaphysics Made since the Time of Kant? Kant and the Metaphysics of Grounding', Eric Watkins explores the relationship between Kant's metaphysics and current debates around grounding. He maintains that both Kant and present metaphysicians working on this topic are interested in the same kind of metaphysical dependence relationships. Furthermore, he argues that while, on the one hand, contemporary work on grounding can help us understand what a 'condition' is for Kant, on the other, Kant's approach to 
metaphysics can still be useful today when it comes to setting limits to our metaphysical investigations.

Dietmar Heidemann, author of the seventh paper on 'Kant and the Forms of Realism', argues that Kant's distinction between empirical and transcendental realism is still relevant today. This is not understood as a normative claim. Rather, Heidemann believes that this distinction lies in the background of the way in which we still distinguish different forms of realism, such as non-metaphysical and metaphysical realism. Heidemann spells out three methodological criteria by means of which Kant classifies the forms of realism and shows how these criteria can 'serve as general classificatory tools of distinguishing forms of realism even beyond Kant'.

The eighth paper, written by Andrew Stephenson and titled 'How to solve the knowability paradox with transcendental epistemology', uses Kant's philosophy to provide a novel solution to the 'knowability paradox'. Famously, the paradox appears to show that the moderate claim that all truths are knowable entails the extreme claim that all truths are known. This generates a problem for semantic anti-realists, who customarily wants to maintain knowability while denying omniscience. Stephenson argues that Kant's transcendental epistemology, in particular his account of a special kind of reflective self-knowledge called 'apperception', provides the material for a powerful anti-realist response. The solution is a moderate form of 'restriction strategy': it proceeds by restricting the validity of the knowability principle to what Stephenson calls 'non-epistemic' statements. Such strategies are not new, but, Stephenson argues, the one based on Kant's transcendental epistemology is an improvement over existing attempts.

Finally, the ninth paper, 'Points of View: Kant on Perspectival Knowledge' by Michela Massimi, spells out a new way in which Kant can be relevant to current debates on perspectival knowledge. While Kant is customarily seen as one of the chief figures in the history of perspectivalism, this is done using an understanding of perspectival knowledge which Massimi calls 'knowledge from a vantage point'. However, Kant provides an account of a second type of perspectival knowledge, which Massimi calls 'knowledge towards a vantage point'. Massimi reconstructs Kant's views on this second kind of perspectival knowledge and traces its relevance for contemporary philosophers of science.

Acknowledgements Some of the papers in the special issue were originally presented at a workshop on 'The Current Relevance of Kant's Method in Philosophy' that took place at the University of Frankfurt in July 2016. Speakers at the event were: Dietmar Heidemann, Thomas Land, Jessica Leech, Michela Massimi, Tobias Rosefeldt, Nicholas Stang, Thomas Sturm, Eric Watkins, Lea Ypi, and myself. The special issue is part of a research project sponsored by the Deutsche Forschungsgemeinschaft on 'Kant, Transcendental Strategies and Philosophical Antinomies' that I ran at the University of Frankfurt from October 2014 until May 2018. ${ }^{3}$ I thank the participants of the workshop and the authors of this special issue for their contribution. I would also like to thank the Deutsche Forschungsgemeinschaft for financially supporting the project and both the Deutsche Forschungsgemeinschaft and the Vereinigung von Freunden

\footnotetext{
3 Among other publications arising from the latter project see in particular: Gava (2018, 2019a, b, c, forthcoming).
} 
und Förderern of the University of Frankfurt for sponsoring the workshop. Finally, I thank Otávio Bueno for his advice during the realization of the special issue.

\section{References}

Brueckner, A. L. (1983). Transcendental arguments I. Noûs, 17(4), 551.

Brueckner, A. L. (1984). Transcendental arguments II. Noûs, 18(2), 197.

Chignell, A. (2007a). Belief in Kant. The Philosophical Review, 116(3), 323-360.

Chignell, A. (2007b). Kant's concepts of justification. Noûs, 41(1), 33-63.

Friedman, M. (2001). Dynamics of reason: the 1999 Kant Lectures at Stanford University. Stanford: CSLI Publications.

Gava, G. (2017a). Transzendentale Argumente. In: Markus Schrenk (Ed.), Handbuch Metaphysik (pp. 410-415). J. B. Metzler: Stuttgart and Weimar.

Gava, G. (2017b). Transcendental arguments. In D. Pritchard (Ed.), Oxford bibliographies in philosophy. Oxford: Oxford University Press. https://doi.org/10.1093/OBO/9780195396577-0357.

Gava, G. (2018). Kant, Wolff, and the method of philosophy. Oxford Studies in Early Modern Philosophy, $8,271-303$

Gava, G. (2019a). Kant, the third antinomy and transcendental arguments. Pacific Philosophical Quaterly, 100, 453-481.

Gava, G. (2019b). C. I. Lewis, Kant, and the reflective method of philosophy. British Journal for the History Philosophy, 27, 315-335.

Gava, G. ed. (2019c). Kant's philosophical method: receptions and transformations, Special Issue, British Journal for the History of Philosophy, 27(2).

Gava, G. (forthcoming). Kant's method in the Critique of pure reason.

Leech, J. (2012). Kant's modalities of judgment. European Journal of Philosophy, 20(2), 260-284.

McDowell, J. (1996). Mind and world, with a new introduction by the author. Cambridge, MA: Harvard University Press.

Pereboom, D. (2019). Kant's transcendental arguments. In E. N. Zalta (Ed.), The Stanford encyclopedia of philosophy, Spring 2019 edn. http://plato.stanford.edu/archives/spr2019/entries/kant-transcende ntal/.

Stang, N. (2016). Kant's modal metaphysics. Oxford: Oxford University Press.

Stern, R. (2019). Transcendental arguments. In E. N. Zalta (Ed.), The Stanford encyclopedia of philosophy, Summer 2019 edn. http://plato.stanford.edu/archives/sum2019/entries/transcendental-argum ents/.

Stern, R. (2000). Transcendental arguments and scepticism: answering the question of justification. Oxford: Oxford University Press.

Strawson, P. (1959). Individuals: an essay in descriptive metaphysics. London: Methuen.

Strawson, P. (1966). The bounds of sense: an essay on Kant's Critique of pure reason. London: Methuen.

Stroud, B. (1968). Transcendental arguments. The Journal of Philosophy, 65(9), 241.

Stroud, B. (1994). Kantian argument, conceptual capacities, and invulnerability. In P. Parrini (Ed.), Kant and contemporary epistemology (pp. 231-251). Netherlands: Springer.

Publisher's Note Springer Nature remains neutral with regard to jurisdictional claims in published maps and institutional affiliations. 